UDC 640.4:339.13

JEL Classification: M30, M34

http://doi.org/10.21272/mmi.2019.2-09

\author{
Richard Fedorko, \\ University of Presov in Presov, Slovakia \\ Radovan Bacik, \\ University of Presov in Presov, Slovakia \\ Maria Olearova, \\ University of Presov in Presov, Slovakia \\ Martin Rigelsky, \\ University of Presov in Presov, Slovakia \\ Peter Breyl, \\ Technical University of Kosice, Slovakia
}

\title{
IMPACT OF ANCILLARY SERVICES ON THE HOTEL RATING IN VISEGRAD GROUP COUNTRIES
}

Abstract. The aim of this article is to find out, as a result of research carried out within the Visegrad Group countries, how complementary services offered by hotels affect customer ratings and the willingness of customers to recommend the hotel. We were collecting primary data, the crucial factor for the selection of hotels was the identification of the suitable Expedia.com (travel booking portal) rating, which focused on the post-stay evaluation of hotels in the Visegrad Group countries. We used automatic data collection for the observed variables (evaluations) within the selected hotel ratings. The total of 345175 evaluations of 1500 hotels were analysed. Focus was given to $\%$ of guests to recommend hotels in relation with the selected variables. Data collection was carried out in the first half of 2017. The main general idea of research results is: there are significant linkages between the offered services that are intended as an integral structure of the hotel offer and customer ratings, along with the percentage representation of the customer's recommendation for a particular accommodation facility. The relationship as such is defined by the very nature of a particular supplementary service, and therefore negative impacts can be assumed, in the Smoke-free property. We argue that there is a relationship between perceived quality of service and willingness of recommendation in the sample. Meeting customer needs through additional services can increase the positive feedback on the accommodation and thus build a stable competitive advantage. The secondary aim of this paper is to help hotels with their marketing strategies. According to this, they will better understand the factors that influence the customer satisfaction. The analysis was conducted based on the research gap in the studies related to the factors which affect the satisfaction of customers of entities providing accommodation services.

Keywords: tourism, reputation, marketing communication, hotels, Visegrad Group.

Introduction. Consumer behaviour, as well as its decision-making before purchasing, during the purchase, as well as after the purchase and the consumption phase, has a significant impact on the success of the B2C market (Albert, 2016). A fundamental condition for an organization to effectively serve customers and to make them satisfied and to gain their loyalty is recognition of their preferences, motives, attitudes, and decision-making - in a nutshell: awareness of consumer behaviour and its patterns (Minh \& Huu, 2016; Richterova et al., 2015; Stefko et al., 2010).

It should be emphasized that with the purchase of goods or services the consumer behaviour process does not end. The last stage of this process is according to Richterova et al. (2010), is primarily includes the consumption or use of the acquired product, but also includes the evaluation as the product selected has actually met the consumer expectations.

An important part which can significantly influence consumer behaviour is the assessment (review) from other customers. Especially in today's technical world, people in companies are affected by reviews on the Internet or on social networks (Ungerman, 2018; Paunescu \& Moraru, 2018).

Literature Review Nowadays, a modern traveller is looking for quality and value, and he's much more confident in making decisions and puts trust in other travellers instead of other traditional forms of

Cite as: Fedorko, R., Bacik, R., Olearova, M., Rigelsky, M., \& Breyl, P. (2019). Impact of Ancillary Services on the Hotel Rating in Visegrad Group Countries. Marketing and Management of Innovations, 2, 99-107. http://doi.org/10.21272/mmi.2019.2-09 
advertising (Collins, 2016; Leung et al., 2013).

Customer reviews in this context can also be understood as one of the components of online reputation. Miller (2015) in his publication, states that the reputation of the company reflects the perception and appreciation of its value, product quality, services and social activity. Internet reputation, however, for hoteliers is not just a marketing area that can be monitored and respond to it. It is also a sphere that can be actively influenced by simple tools and learn to profit from it (Gavurova et al., 2016, 2017). In the first place, it is necessary to distinguish between own tools and the possibility of obtaining feedback and the tools provided by intermediaries - on travel and booking portals (Zamboriova, 2009).

There are a number of studies in the world which tell us about the relationship between customer reviews and credibility according to customers. Specifically, the estimated weight of reviews for overall business confidence has varied in various studies, from, for example, $69 \%$ in a large Nielsen (2013) survey, conducted in 58 countries to a much higher percentage, $88 \%$ for example, in a survey of the BrightLocal company (Anderson, 2014). Simply, people believe in reviews from other customers rather than paid advertising.

Another study focusing on the selected issues, points to the extraordinary increase in the importance of online customer reviews. The study points out that in 2016 the number of online reviewers comparing with personal recommendations grew by $10 \%$ over the previous year. The level of those who do not trust consumer reviews, on the contrary, dropped rapidly from $20 \%$ to only $4 \%$. In addition, $27 \%$ of respondents admitted in 2016 that they trust online reviews if they are authentic (Statista, 2017a). Among other things, we found that $74 \%$ of respondents, on the basis of positive customer reviews, increased their trust towards businesses (Statista, 2017b). Positive customer reviews in up to $81 \%$ of cases encourage hotel guests to write online reviews (TripAdvisor, 2013). On the contrary, $60 \%$ of respondents have been arguing that negative references raise questions about the quality of the company (Statista, 2017b).

As part of tourism, interesting data from the TripBarometer from TripAdvisor (Gonzalo, 2013), where it is stated that up to $93 \%$ of travelers from all over the world are influenced by online reviews when deciding to book accommodation. At the same time, more than half of travellers $(51 \%)$ leave a review online after returning.

There are many other studies in the world that point to the importance of the issue under consideration. We can at least mention the research of the authors like Bucko et al. (2017), Svec et al. (2015), Racherla et al. (2012), Sparks \& Browning (2011), Vermeulen \& Seegers (2009).

It can be noticed that while a number of online consumer reviews make it easier for travellers to find information, it is relatively difficult to process and assess their usefulness. Extensive travel information available through social media will provide lower costs for people, but on the other hand they have to stimulate more effort to search for them (Frias et al., 2008; Soltes \& Gavurova, 2015; Jelinkova et al., 2017). In other words, the tendency is to reduce search costs, but to increase cognitive costs (Bellman et al., 2006).

Online reviews are a key factor in online tourism marketing. Web Portals with useful reviews offer customers more potential value and help build their confidence in purchasing decisions (Sussman \& Siegal, 2003). In addition, they help build the brand name as well as its credibility (Sheenan, 2010; Kljucnikov et al., 2018).

Methodology and research methods. The research conducted deals with the issue of online customer reviews. In particular, it focuses on customer buying habits in the form of their quality assessment of accommodation services within the Visegrad group - V4 (i.e. Slovakia, Hungary, Czech Republic and Poland).

The purpose of the research was to find out how complimentary services (Free WiFi, Restaurant, Laundry facilities, Free private parking, Smoke free property, Business centre, Multilingual staff, 
Concierge services, 14-hour front desk, Indoor pool, Grocery store, Babysitting) influence the customer's rating and the willingness of the customers to recommend the hotel.

In relation to the above-mentioned main objective, the following states will be pursued in the light of the following research questions:

- R.Q.1.: Are there significant dependencies between service offerings and customer ratings?

- R.Q.2.: Are there significant dependencies between the services offered and the percentage of the accommodation recommendation?

The first step of the analysis was the identification of online portals focusing on the purchasing values of accommodation providers. The decisive factor in this selection was the data completeness condition for the subsequent analysis (absolute values). The choice of suitable portals was also influenced by their popularity, namely the number of active entities providing accommodation, as well as the technical capability for automated data collection. Based on our selection criteria, we were able to identify one online portal. The main reason for not linking multiple portals was the inconsistency of the rated variables given by the portals.

In particular, Expedia.com, Inc (is also a publicly traded company listed under the ticker symbol EXPE on the NADASQ Global Market. There are currently 200+ separate brands under the heading of travel booking sites. Among the most significant ones are the before-mentioned portal, Expedia.com, Hotels.com, Trivago.com, or Hotwire.com) has been identified. Expedia.com is one of the world's leading full-service online travel brands helping travellers easily plan and book travel from the widest selection of vacation packages, flights, hotels, rental cars, rail, cruises, activities, attractions, and services (Expedia, 2017). This portal was founded in 1996, today has localized sites in 33 countries. Expedia.com has over 40 million post-stay reviews and more than 30 million real-time reviews. For research purposes, the following rated variables were identified as: Number of customer ratings, $\%$ of guests recommend hotel (Guests recommending \%), Guest rating (Overall rating), Room cleanliness, Service \& staff, Room comfort, Hotel condition. The next step of the analysis was to identify the subjects providing accommodation services within the monitored portal for subsequent data collection, customer reviews. For data collection purposes, we used the automatic data collection method using a PHP 5.6.17, MySQL 5.7.10 databases, phpMyAdmin 4.4.15.2 MySQL database manager and Apache 2.4.16 web server. With the help of the above-mentioned technologies, a script has been created, which has identified the role within the source code on the sub-pages of the summarizing rated entities providing the accommodation and subsequently recording the selected monitored variables within the database. The implementation of this step took place in several phases in April 2017. As part of this step, we managed to identify a total of 1,500 profiles of accommodation providers suitable for further analysis.

The third step of the analysis was the control of the monitored variables (ratings) within the identified profiles of the investigated subjects. The aim of this step was to identify the suitable subjects (accommodation facilities) for further analysis, identifying the entities which included customer ratings and were not identified as inactive. Entities identified as inactive were not registered. At this stage, the selective condition of the subjects was implemented, with subjects ranging from at least 20 customer reviews to the survey. As in the previous step, the automatic data capture method was used in this script as well. The implementation of data collection itself took place in May 2017. From the data obtained in this step, 1942 subjects were identified with customer reviews. The survey included 1500 (77.24\%) subjects - subjects with more than 20 customer reviews. The analysis of the variables examined is based on a total sample of 345175 customer reviews. A closer look at the structure of the data obtained is provided in Table 1 and Table 2. 
Table 1. Characteristics of the research file - by country

\begin{tabular}{|c|c|c|c|c|c|c|}
\hline Country & $\begin{array}{c}\text { Subjects } \\
(\mathbf{n})\end{array}$ & $\begin{array}{c}\text { Subjects } \\
(\%)\end{array}$ & $\begin{array}{c}\text { Valid } \\
\text { subjects (n) }\end{array}$ & $\begin{array}{c}\text { Valid } \\
\text { subjects (\%) }\end{array}$ & $\begin{array}{c}\text { Reviews } \\
(\mathbf{n})\end{array}$ & $\begin{array}{c}\text { Reviews } \\
(\%)\end{array}$ \\
\hline SK & 232 & 28,78 & 107 & 7,13 & 13934 & 4,04 \\
\hline CZ & 559 & 44,13 & 545 & 36,33 & 154685 & 44,81 \\
\hline PL & 857 & 15,14 & 642 & 42,8 & 101752 & 29,48 \\
\hline HU & 232 & 11,95 & 206 & 13,73 & 74804 & 21,67 \\
\hline Total & $\mathbf{1 9 4 2}$ & $\mathbf{1 0 0}$ & $\mathbf{1 5 0 0}$ & $\mathbf{1 0 0}$ & $\mathbf{3 4 5} \mathbf{1 7 5}$ & $\mathbf{1 0 0 , 0 0}$ \\
\hline
\end{tabular}

Sources: developed by the authors.

Table 2. Characteristics of the research group - by hotel category

\begin{tabular}{|c|c|c|c|c|c|c|c|c|}
\hline \multirow{2}{*}{$\begin{array}{c}\text { Hotel } \\
\text { stars }\end{array}$} & \multicolumn{2}{|c|}{ SK } & \multicolumn{2}{c|}{ CZ } & \multicolumn{2}{|c|}{ HU } & \multicolumn{2}{c|}{ PL } \\
\hline & $\mathbf{( n )}$ & $(\mathbf{\%})$ & $(\mathbf{n})$ & $(\%)$ & $(\mathbf{n})$ & $(\%)$ & $(\mathbf{n})$ & $(\%)$ \\
\hline $\mathbf{1}$ & 0 & 0 & 0 & 0 & 1 & 0,49 & 9 & 1,4 \\
\hline $\mathbf{1 , 5}$ & 1 & 0,93 & 0 & 0 & 1 & 0,49 & 5 & 0,78 \\
\hline $\mathbf{2}$ & 9 & 8,41 & 15 & 2,75 & 11 & 5,34 & 73 & 11,37 \\
\hline $\mathbf{2 , 5}$ & 1 & 0,93 & 4 & 0,73 & 2 & 0,97 & 10 & 1,56 \\
\hline $\mathbf{3}$ & 36 & 33,64 & 176 & 32,29 & 64 & 31,07 & 263 & 40,97 \\
\hline $\mathbf{3 , 5}$ & 8 & 7,48 & 46 & 8,44 & 29 & 14,08 & 74 & 11,53 \\
\hline $\mathbf{4}$ & 42 & 39,25 & 244 & 44,77 & 72 & 34,95 & 169 & 26,32 \\
\hline $\mathbf{4 , 5}$ & 2 & 1,87 & 16 & 2,94 & 7 & 3,4 & 1 & 0,16 \\
\hline $\mathbf{5}$ & 8 & 7,48 & 44 & 8,07 & 19 & 9,22 & 36 & 5,61 \\
\hline Total & $\mathbf{1 0 7}$ & $\mathbf{1 0 0}$ & $\mathbf{5 4 5}$ & $\mathbf{1 0 0}$ & $\mathbf{2 0 6}$ & $\mathbf{1 0 0}$ & $\mathbf{6 4 2}$ & $\mathbf{1 0 0}$ \\
\hline
\end{tabular}

Sources: developed by the authors.

The analysed variables determined by the research questions were processed by the Goodman and Kruskal correlation gamma coefficient with respect to the structure of the scales. In the first research question, as a dependent variable, the Guest rating at the ordinal level gave at the theoretical interval from 1 to 5 intervals of one tenth as independent variables the individual services provided by the hotel at the dichotomic ordinate scale. The second research question had a dependent variable percentage of the recommendation and independent individual hotel services, thus identical to the first research questions.

Results. As it can be seen from the Figure1, in the vast majority of cases, the presence of the service indicates an average customer rating better than in the absence of a service. On the other hand, when there is a "free self-parking» service, a decrease in the average hotel rating is indicated. This scenario can also be accessed by a service such as Multilingual staff. Looking at the country itself, in the Czech Republic the highest difference with the dominant value, indicating a positive rating, was recorded in the Babysitting service, just like in Hungary. In Poland, this service was the free WiFi and in Slovakia the Concierge services. The highest negative difference between the negative average hotel customer rating and the positive one in the Czech Republic was recorded for the 14-hour front desk, in Hungary it was the free self-parking service. In Poland, it was the Multilingual staff and in Slovakia the Smoke-free property. About these services we can say that their characteristics or quality of performance are rather detrimental to the average consumer rating. The following table informs us about the significance of the facts. 


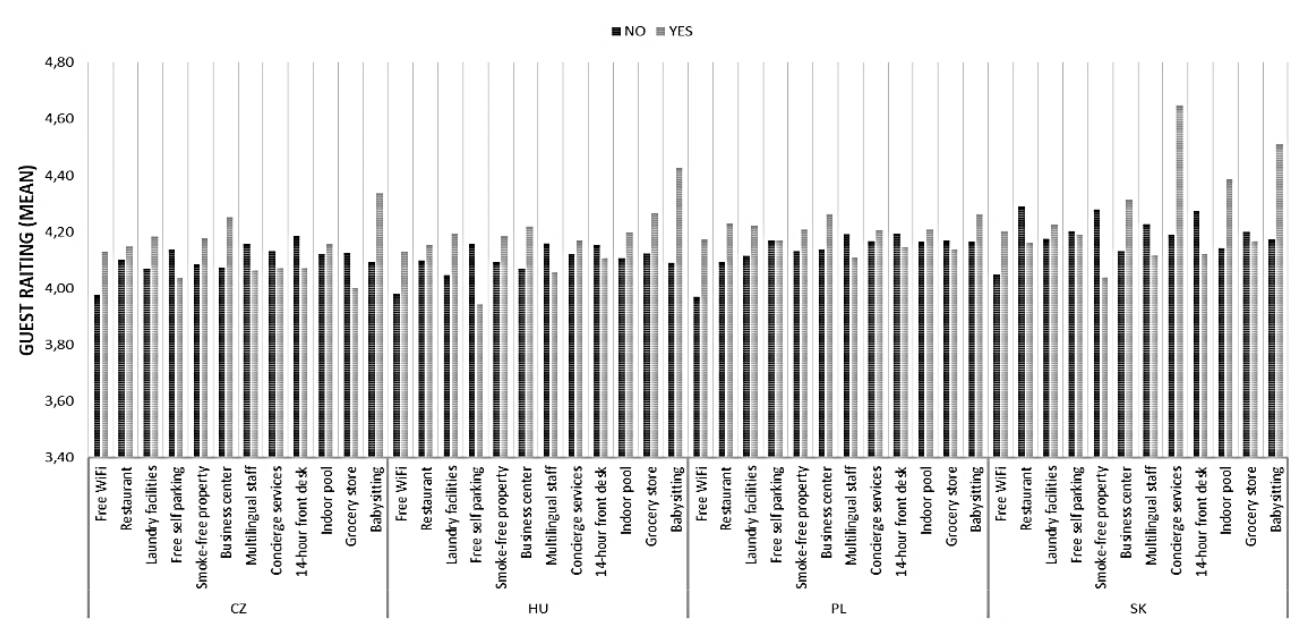

Sources: developed by the authors.

In the case of Table 3, with black and white are marked with services that significantly affect customers' hotel ratings. As we can see between the significant services, services with both positive and negative impact on customer ratings appeared. Both the nature of the service, the quality it provides, or the impact of other services may be the cause of both positive and negative impacts. It is advisable to take into account the level of association of the given services and the customer evaluation. An association of up to 0.2 in absolute value, although significant, does not represent a measure on which to construct constant assumptions. The rate from 0.2 to 0.4 is controversial, but at a rate above 0.4 is when we are talking about the average rate of the association, which is not negligible.

Table 3. Output p-value (critical significance levels 0.05 ) and correlation of guest rating and services between the V4 countries

\begin{tabular}{|c|c|c|c|c|c|c|c|c|c|c|c|c|c|}
\hline \multicolumn{2}{|c|}{$\begin{array}{l}\text { Country and } \\
\text { Services }\end{array}$} & \multirow{2}{*}{\begin{tabular}{|r|} 
Free WiFi \\
, 230 \\
\end{tabular}} & \multirow{2}{*}{$\begin{array}{r}\text { Restaurant } \\
, 191 \\
\end{array}$} & \multirow{2}{*}{$\begin{array}{r}\begin{array}{r}\text { Laundry } \\
\text { facilities }\end{array} \\
, 001\end{array}$} & \multirow{2}{*}{$\begin{array}{r}\begin{array}{r}\text { Free self } \\
\text { parking }\end{array} \\
, 290 \\
\end{array}$} & \multirow{2}{*}{$\begin{array}{r}\begin{array}{c}\text { Smoke- } \\
\text { free } \\
\text { property }\end{array} \\
, 021 \\
\end{array}$} & \multirow{2}{*}{$\begin{array}{r}\begin{array}{c}\text { Business } \\
\text { center }\end{array} \\
, 000\end{array}$} & \multirow{2}{*}{\begin{tabular}{|r|}
$\begin{array}{c}\text { Multilingual } \\
\text { staff }\end{array}$ \\
, 005
\end{tabular}} & \multirow{2}{*}{$\begin{array}{r}\begin{array}{r}\text { Concierge } \\
\text { services }\end{array} \\
, 435 \\
\end{array}$} & \multirow{2}{*}{\begin{tabular}{|r|}
$\begin{array}{c}14 \text {-hour } \\
\text { front desk }\end{array}$ \\
, 002 \\
\end{tabular}} & \multirow{2}{*}{$\begin{array}{r}\begin{array}{c}\text { Indoor } \\
\text { pool }\end{array} \\
, 648 \\
\end{array}$} & \multirow{2}{*}{$\begin{array}{r}\begin{array}{c}\text { Grocery } \\
\text { store }\end{array} \\
, 808 \\
\end{array}$} & \multirow{2}{*}{$\begin{array}{r}\text { Babysitting } \\
, 000\end{array}$} \\
\hline$C 7$ & $p$ value & & & & & & & & & & & & \\
\hline$c 2$ & Gamma & ,205 & ,069 & ,176 &,- 092 &, 122 & ,254 &,- 154 & \begin{tabular}{|l|}
-066 \\
\end{tabular} &,- 161 & 039 &,- 073 &, 36 \\
\hline \multirow{2}{*}{ HU } & $p$ value & ,962 & ,391 &, 016 &, 020 & ,149 & 022 & ,121 & ,700 & 346 & .276 &, 426 & ,002 \\
\hline & Gamma &,- 019 & ,074 & ,203 &,- 287 & ,130 & ,200 &,- 138 & ,055 &,- 083 & ,114 & ,198 &, 500 \\
\hline \multirow{2}{*}{ PL } & $p$ value & 058 & ,000 & ,001 & 829 & ,006 & ,000 & ,015 & ,315 & ,028 & ,387 & ,712 &, 072 \\
\hline & Gamma & 366 & ,218 &, 158 &,- 013 &, 134 & , 198 &,- 132 & 099 &,- 108 & 069 &,- 049 & ,207 \\
\hline \multirow{2}{*}{ SK } & $p$ value & ,470 &, 402 & ,839 & 921 & 055 & ,078 & ,132 & ,153 & ,364 & 021 &, 713 & ,035 \\
\hline & Gamma & ,290 & -105 & ,024 &, 013 & -240 & ,208 &,- 195 & ,788 &,- 109 &, 317 &,- 123 &, 481 \\
\hline \multirow[b]{2}{*}{ Total } & $p$ value &, 042 & ,000 & ,000 & ,273 & ,002 & ,000 & , 000 & 867 & ,000 & , 030 & 808 &, 000 \\
\hline & Gamma & ,237 & , 126 & , 162 & $\begin{array}{l}-048 \\
-,\end{array}$ &, 099 & ,220 & $-1,150$ & ,010 & -128 & , 104 & $\begin{array}{l}-, 026 \\
\end{array}$ & ,33 \\
\hline
\end{tabular}

As can be seen in Figure 2, the average hotel recommendations are dominated by positive outputs in the presence of services, though often in very small variations. In Slovakia, the most noticeable difference can be observed in Concierge services, in Poland and Hungary for free WiFi. In the Czech Republic for Babysitting. On the other hand, the most negative impact on the average rate of recommendation in Slovakia is the Restaurant and the Smoke-free property. In Poland, the differences were very small, but it negatively influences, for example, the Indoor pool or the Free self-parking as well 

Group Countries

as in the Czech Republic and in Hungary, a negative recommendation is the Restaurant. It can be said these services are rather toxic than useful in the average hotel recommendation. The following table informs us about the significance of the facts. As we mentioned the reasons for the negative impact, the characteristics of the service itself, the quality of its performance, or the quality of the transfer may have a high degree of impact on other services.

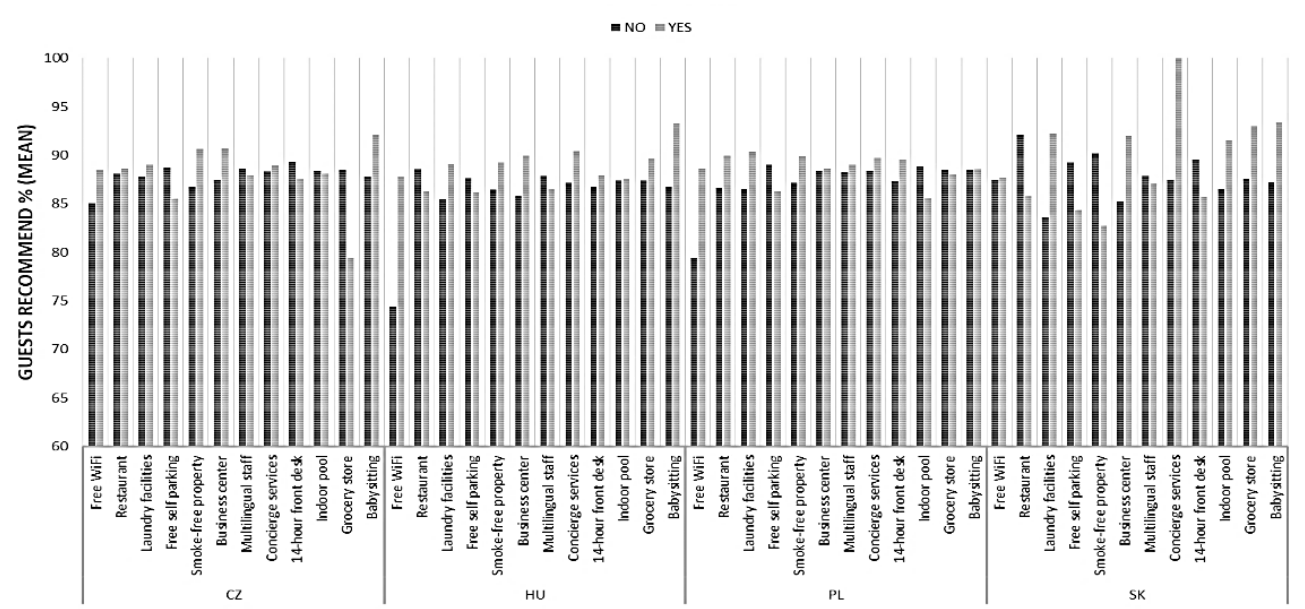

Figure 2. Guests recommending (mean) and Services

Sources: developed by the authors.

As in the above Table, Table 4 also shows a significant rate of service association per percentage of hotel recommendations in black with white writing. Positive association rates have a blue and the negative ones have a red text colour. In terms of intensity, stronger judgments cannot be made, as we only record weak and very weak associations.

Table 4. Output p-value (critical significance levels 0.05 ) and correlation of guests recommend and services between the $\mathrm{V} 4$ countries

\begin{tabular}{|c|c|c|c|c|c|c|c|c|c|c|c|c|c|}
\hline \multicolumn{2}{|c|}{$\begin{array}{l}\text { Country and } \\
\text { Services }\end{array}$} & ree WiFi & Restaurant & $\begin{array}{l}\text { Laundry } \\
\text { facilities }\end{array}$ & $\begin{array}{c}\text { Free self } \\
\text { parking }\end{array}$ & $\begin{array}{c}\text { Smoke- } \\
\text { free } \\
\text { property }\end{array}$ & $\begin{array}{c}\text { Business } \\
\text { center }\end{array}$ & $\begin{array}{c}\text { Multilingual } \\
\text { staff }\end{array}$ & $\begin{array}{l}\text { Concierge } \\
\text { services }\end{array}$ & $\begin{array}{c}\text { 14-hour } \\
\text { front desk }\end{array}$ & $\begin{array}{c}\text { Indoor } \\
\text { pool }\end{array}$ & $\begin{array}{l}\text { Grocery } \\
\text { store }\end{array}$ & Babysitting \\
\hline \multirow{2}{*}{$\mathrm{CZ}$} & p value & ,101 & ,804 & ,063 & 803 & ,001 & ,026 & , 174 & ,635 & ,002 & 593 & ,103 &, 0 \\
\hline & Gamma &, 235 & 013 & ,097 &, 026 &, 164 &, 122 &,- 076 & ,040 &,- 158 &,- 046 &,- 462 & , 146 \\
\hline \multirow{2}{*}{$\mathrm{HU}$} & $p$ value &, 743 & ,379 & ,384 &, 930 & ,289 & , 150 & ,371 & ,361 & ,963 & .546 & ,604 &, 0 \\
\hline & Gamma & ,122 & $\begin{array}{l}-074 \\
-, 07\end{array}$ & ,075 &, 013 & ,091 & , 120 &,- 079 & ,127 & ,004 & ,066 &,- 107 & 345 \\
\hline \multirow{2}{*}{$\mathrm{PL}$} & $p$ value & ,101 & ,078 & ,165 & ,633 &, 005 & ,153 & ,466 & 677 & ,548 & ,007 &, 936 & , 88 \\
\hline & Gamma & 345 & 091 & ,071 &,- 034 & , 139 &,- 077 &, 041 & ,040 &, 030 &,- 202 &,- 011 &,- 016 \\
\hline \multirow{2}{*}{ SK } & $p$ value &, 915 & , 106 & ,075 & ,937 & , 024 & ,128 &, 284 & .148 & ,069 &, 144 & 688 & .59 \\
\hline & Gamma &,- 041 &,- 214 & ,225 &, 012 &,- 288 & ,189 &,- 143 & 1,000 &,- 222 & .215 & .126 &, 09 \\
\hline \multirow{2}{*}{ Total } & $p$ value & ,030 & ,333 &, 005 & 859 & , 000 & ,238 & ,282 & ,351 & ,064 & ,219 & ,498 & ,030 \\
\hline & Gamma &, 240 & ,031 & ,091 & ,009 & .116 & ,039 &,- 037 & ,053 & $\mid-, 060$ & \begin{tabular}{|l|}
,- 058 \\
\end{tabular} & $\begin{array}{l}-, 076 \\
\end{array}$ & , 10 \\
\hline
\end{tabular}

Sources: developed by the authors.

Conclusions. In general, customers are the basis of the business. Based on this online reputation, it has a tremendous impact on tour operators, namely accommodation facilities. From this point of view, online reputation, also represented in the form of online customer reviews, greatly affects consumer behaviour. From the point of view of competitiveness, the issue can be considered highly topical. 
As we have seen in the previous sections of the article, there are significant linkages between the offered services that are intended as an integral structure of the hotel offer and customer ratings, along with the percentage representation of the customer's recommendation for a particular accommodation facility. So, the research questions are confirmed.

Generally speaking, given the output level, it was argued that the Babysitting service impacts on the quality perceived in the variable customer rating and the willingness to recommend the accommodation positively. The outputs of other services analysed due to their relatively low association rates in both variables cannot be clearly interpreted as a variable that determines the quality as positive. On the other hand, when it is about the Smoke-free property, we are talking about the negative impact mainly in Slovakia. A very negative impact was seen in several countries at the variable 14-hour front desk. In general, facilities should be geared to increasing the potential of the positive impact of complementary services with a positive impact that correlate with the idea of their focus.

This issue offers a relatively wide range of questions and creates scope for a number of analyses. The possibility of analysing the association is more detailed in the classification of variables, but with respect to the outcomes that have been shown to be high by the association, significant deviations are not expected. In conclusion, it is important to emphasize that the issue of online customer reviews and the issue of building the positive online reputation of tourism operators is an important part of the process of enforcing both the virtual market and the offline market.

Author Contributions: Conceptualization, R. F. and R. B.; methodology, M. O.; software, M. R.; validation, P. B., R. F. and R. B; formal analysis, M. O.; investigation, M. R and P. B.; resources, R. F.; data curation, R. B.; writing-original draft preparation, M. O.; writing-review and editing, M. R.; visualization, R. F.; supervision, R. B.; project administration, M. O.; funding acquisition, R. F. and R. B.

Funding: This article is one of the partial outputs under the scientific research grant VEGA $1 / 0609 / 19$ «Research on the development of electronic and mobile commerce in the aspect of the impact of modern technologies and mobile communication platforms on consumer behaviour and consumer preferences» and VEGA 1/0789/17 «Research of e-commerce with relation to dominant marketing practices and important characteristics of consumer behaviour while using mobile device platforms».

\section{References}

Albert, T. A. (2016). The Impact of the Hotel Industry on the Competitiveness of Tourism Destinations in Hungary. Journal of Competitiveness, 8 (4), 85-104.

Anderson, M. (2014, July 07). 88 \% Of Consumers Trust Online Reviews As Much As Personal Recommendations. Retrieved from http://searchengineland.com/88 consumers-trust-online-reviews-much-personal-recommendations- 195803.

Bellman, S., Johnson, E.J., Lohse, G. L., \& Mandel, N. (2006). Designing Marketplaces of the Artificial with Consumers in Mind: Four Approaches to Understanding Consumer Behavior In Electronic Environments. Journal of Interactive Marketing, 20(1), 21-3.

Bucko, J., Kakalejcik, L., \& Ferencova, M. (2017). The internet and its use in pre-purchase stage in Europe and Asia Management of marketing efforts. Polish Journal of Management Studies, 15(2), $16-26$

Collins, T. (2016). Mechanics of Online Reputation Management: Repair \& Control Your Name rr Brand Reputation Online. South Carolina: CreateSpace

Expedia, (2017, May 12). Overview. Retrieved from: http://www.expediainc.com/brands/expedia-com/.

Frias, D.M, Rodriguez, M.A., \& Castaneda, J.A. (2008). Internet vs. travel agencies on pre-visit destination image formation: An information processing view. Tourism management, 29(1), 163-179.

Gavurova, B., Vagasova, T., Kovac, V. (2016). Competitiveness Assessment of Slovak Republic Regions. In: European Financial System 2016. 13th International Scientific Conference of theEuropean Financial Systems, Brno, 2016, 175-+.

Gavurova, B., Soltes, M., Kovac, V. (2017). Application of Cluster Analysis in Process of Competitiveness Modelling of Slovak Republic Regions. Transformations in Business \&Economics, 16(3), pp. 129-147.

Gonzalo, F. (2013, March 16). Online Resources Key To Travel Decision-Making. Retrieved from: http://www.business2community.com/travel-leisure/online-resources-key-to-travel-decision-making-infographic-0437761\#3Hp 
DcedVcALEv4Xx.97.

Jelinkova, D., Tuckova, Z. \& Jurigova, Z. (2017). Market segment of families with children: a new stimulus for modern Czech spa industry?. Journal of International Studies, 10(2), 158-169. doi:10.14254/2071-8330.2017/10-2/12

Leung, D., Law, R., Van Hoof, H., \& Buhalis, D. (2013). Social Media in Tourism and Hospitality: A Literature Review. Journal of Travel \& Tourism Marketing, 30(1-2), 3-22

Kljucnikov, A., Krajcik, V., Vincurova, Z. (2018). International Sharing Economy: the Case of AirBnB in the Czech Republic. Economics and Sociology, 11(2), 126-137. doi:10.14254/2071-789X.2018/11-2/9

Miller, R.E. (2015). The Complete Guide To Online Reputation For Small \& Local Business.Yeovil, England: MDM Publishing.

Minh, N. V., Huu, N. H. (2016). The Relationship between Service Quality, Customer Satisfaction and Customer Loyalty: An Investigation in Vietnamese Retail Banking Sector. Journal of Competitiveness, Vol. 8, Issue 2, pp. 103-116.

Nielsen, (2013, September 17). Under the Influence: Consumer trust in Advertising. Retrieved from:

http://www.nielsen.com/us/en/insights/news/2013/under-the-influence-consumer-trust-in-advertising.html.

Racherla, P., Connolly, D.J., \& Christodoulidou, N. (2013). What determines consumers' ratings of service providers? An exploratory study of online traveler reviews. Journal of Hospitality Marketing \& Management, 22(2), 135-161.

Paunescu, C., \& Moraru, R. (2018). Maximizing Social Value in the hotel online environment using an Analytic Hierarchy Process. Journal of Competitiveness, 10 (1), 106-124.

Richterova, K. et al. (2010). Spotrebitel'skéspravanie. Bratislava: Sprint.

Sheenan, B. (2010). Basics Marketing 02: Online Marketing. Lausanne: AVA Publishing.

Soltes, V., \& Gavurova, B. (2015). Modification of performance measurement system in the intentions of globalization trends. Journal of Management Studies, 11(2), 160-170.

Sparks, B., \& Browning, V. (2011). The impact of online reviews on hotel booking intentions and trust. Tourism Management, 32(6), 310-1323.

Statista, (2017a, August 25). Effect of online reviews on local business customer opinion 2016. Retrieved from https://www.statista.com/statistics/315751/online-review-customer-opinion/.

Statista, (2017b, August 25). Trust in online customer reviews 2016. Retrieved from: https://www.statista.com/statistics/315755/online-custmer-review-trust/.

Stefko, R., Habanik, J., \& Sindleryova, I.B. (2010). Marketing instrumentary in the process of project acceptation within the acceleration of back-warded regions development. Ekonomicky casopis, 58 (5), 512-526.

Sussman, S.W., \&Siegal, W.S. (2003). Information Influence in Organizations: An Integrated Approach to Knowledge Adoption. Information Systems Research, 14, 47-56.

Svec, M., Olsovska, A., \& Mura, L. (2015). Protection of an «Average Consumer» in the Digital Society - European Context. International Scientific Conference on Marketing Identity. Marketing Identity: Digital Life, Book Series: Marketing Identity, 273-282

TripAdvisor, (2013, March 19) Online Resources Key To Travel Decision-Making. Retrieved from: https://www.socialmediatoday.com/content/online-resources-key-travel-decision-making.

Ungerman, O., Dedkova, J., \&Gurinova, K. (2018). The impact of marketing innovation on the competitiveness of enterprises in the context of industry 4,0. Journal of Competitiveness, 10 (2), 132-148.

Vermeulen, I.E., \& Seegers, D. (2008). Tried and tested: The impact of online hotel reviews on consumer consideration Tourism Management, 30(1), 123-127.

Zamboriova, J. (2009, May 15). Budovaniepozitivnej online reputacie. Retrieved from: http://www.hotelblog.sk/ clanky/strategie/budovanie-pozitivnej-online-reputacie\#.WYrqHinfOM8.

Річард Федорко, Пряшівський університет у Пряшеві (Словаччина);

Радован Бачік, Пряшівський університет у Пряшеві (Словаччина);

Марія Олеарова, Пряшівський університет у Пряшеві (Словаччина);

Мартін Рігельський, Пряшівський університет у Пряшеві (Словаччина);

Пітер Брейль, Технічний університет у Кошице (Словаччина).

Вплив додаткових послуг на рейтинг готелів країн Вишеградської групи

Головною метою статті є визначення впливу додаткових послуг готелів країн Вишеградської групи на оцінки клієнтів та їх готовність у подальшому рекомендувати готель. Основою даного дослідження $\epsilon$ розрив у напрацюваннях, які пов'язані з науково-методичними підходами до оцінки факторів впливу на рівень задоволеності клієнтів, які користуються житловими послугами. Піठ час збору первинних даних головним критерієм відбору готелів $є$ їх рейтинг, визначений за допомогою порталу бронювання білетів Expedia.com, який спрямований на аналіз відгуків про готелі країн Вишеградської групи. Емпіричне дослідження проведено з використанням автоматичного збору даних для оцінки визначених змінних в межах обраних готельних рейтингів. Загалом сукупна вибірка даного дослідження становить 345175 оцінок 1500 готелів. При цьому автори зосередились на питомій вазі клієнтів, які рекомендували готелі за обраними для дослідження змінними у першій 
R. Fedorko, R. Bacik, M. Olearova, M. Rigelsky, P. Breyl. Impact of Ancillary Services on the Hotel Rating in Visegrad Group Countries

половині 2017 року. Головною метою статmі $\epsilon$ визначення зв'язків між запропонованими додатковими послугами, які розглядаються як цілісна структура пропозицій готелів та оцінками клієнтів, разом із питомою вагою рекомендацій клієнтів для певних апартаментів. За результатами дослідження визначено наявність статистично значимого взаємозв'язку між сприйняттям споживачами якості обслуговування та їх готовністю рекомендувати помешкання у межах даної вибірки. При цьому задоволення потреб клієнтів через додаткові послуги може підвищити позитивні відгуки про помешкання, та, у свою чергу, забезпечити стійкі конкурентні переваги на готельному ринку. Відповідно до отриманих результатів авторами розроблено маркетингові стратегії для готелів країн Вишеградської групи. Авторами зазначено, що отримані результати сприяють поглибленню досліджень факторів впливу на рівень задоволеності клієнтів. Ключові слова: туризм, репутація, маркетингова комунікація, готелі, Вишеградська група.

Manuscript received: 26.02.2019.

(C) The author(s) 2019. This article is published with open access at Sumy State University. 